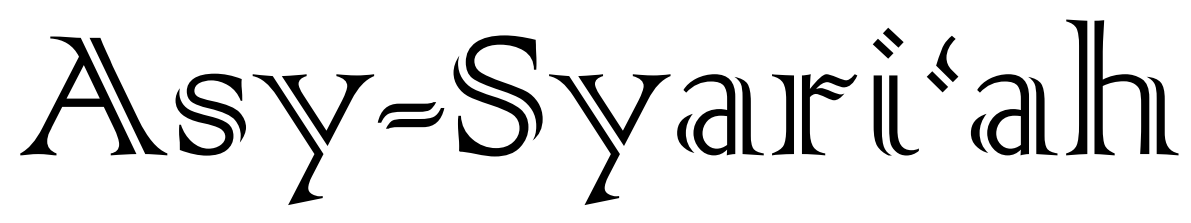

- $\quad$ The Role of Religious Court in Islamic Law Reform in Indonesia

$(125-134)$ Amran Suadi

- Rechtvinding tentang Waris Beda Agama di Pengadilan Agama ( $135-158)$ Kota Bandung Siah Khosyi'ah dan Aan Tsamrotul Fuadah

- Dualisme Kedudukan dan Tanggung Jawab Notaris dalam ( $159-170)$ Tatanan Sistem Hukum Nasional Isis Ikhwansyah dan Indra Prayitno

- Nilai-Nilai Keislaman dalam Konstitusi Kesultanan Ngayogyakarta Hadiningrat

Abdul Rohim Al Wafi

- Anotasi Putusan Dissenting Opinion dalam Putusan Kasasi Taufik Maulani

- Dampak Poligami Siri Terhadap Kehidupan Keluarga di Desa Cigugur Girang, Bandung Barat Ade Darmawijaya

- Azas-Azas dan Landasan Distribusi Pendapatan dalam Islam $(221-232)$ Rani Mulyani dan Iwan Setiawan

- Eksistensi Riba dalam Investasi Wakaf Uang di Luar Bank (233-244) Syari'ah

Khoir Affandi

- Hak Pendidikan bagi Penyandang Disabilitas dalam Perspektif Hukum Perdata dan Hak Asasi Manusia

Ikbar Maulana Malik

- Perspektif Hukum Islam dalam Penyelesaian Sengketa Melalui ( $257-280$ ) Mediasi di Badan Penyelesaian Sengketa Konsumen Kota Mataram Irma Istihara Zain 


\section{Asy-Syauri'ah}

Volume 21, Number 2, 2019

\section{EDITOR-IN-CHIEF}

Ine Fauzia

\section{EDITORIAL BOARD}

Sofyan al-Hakim, UIN Sunan Gunung Djati Bandung, Indonesia Deni Kamaludin Yusup, UIN Sunan Gunung Djati Bandung, Indonesia Meria Utama, Fakultas Hukum Univrsitas Sriwijaya, Indonesia Dewi Mayaningsih, UIN Sunan Gunung Djati Bandung, Indonesia Andrey Sujatmiko, Fakultas Hukum Universitas Trisakti, Jakarta, Indonesia Hetty Hassanah, Universitas Komputer Indonesia, Indonesia

\section{PEER-REVIEWERS}

Muhammad Irfan Helmy, IAIN Salatiga, Semarang, Indonesia Ahmad Ali Nurdin, UIN Sunan Gunung Djati Bandung Tajul Arifin, UIN Sunan Gunun Djati Bandung, Indonesia Mohamad Anton Athoillah, UIN Sunan Gunung Djati Bandung, Indonesia Mrs. Renny Supriyatni, Universitas Padjadjaran, Indonesia Ahmad Tholabi Karlie, UIN Syarif Hidayatullah Jakarta, Indonesia Ija Suntana, UIN Sunan Gunung Djati Bandung, Indonesia Zezen Zaenal Mutaqin, University of California, Los Angeles, United States Ahmad Fathonih, UIN Sunan Gunung Djati Bandung, Indonesia Rahman Syamsuddin, Universitas Islam Negeri Alauddin Makassar, Indonesia

\section{PROOFREADER/DESIGN COVER}

Nanang Sungkawa

\section{LAYOUT EDITOR}

Opik Rozikin

Asy-Syari' ah has been accredited based on the determination of Director General of Research and Development Strengthening, Ministry of Research, Technology and Higher Education of Republic of Indonesia, No. 14/E/KPT/2019 (valid until 2023). 


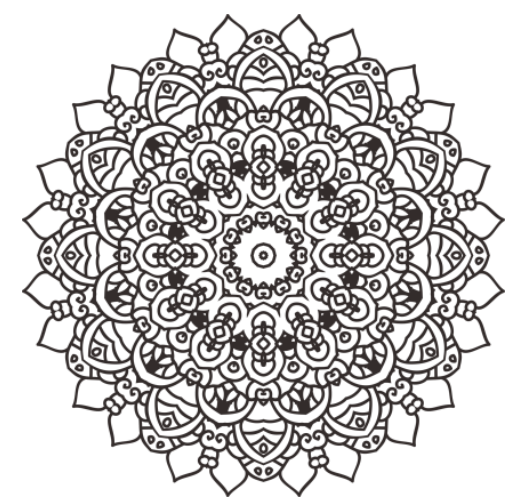

\title{
PERSPEKTIF HUKUM ISLAM DALAM PENYELESAIAN SENGKETA MELALUI MEDIASI DI BADAN PENYELESAIAN SENGKETA KONSUMEN KOTA MATARAM
}

\author{
Irma Istihara Zain \\ Fakultas Syariah dan Hukum UIN Mataram \\ Email: istiharairmag6@gmail.com
}

\begin{abstract}
The procedures for implementing mediation dispute resolution in car financing according to Islamic law and Positive Law are the same as prioritizing the concept of justice, but in BPSK there are 3 stages, namely petition, trial, and verdict. Whereas in the concept of Islamic law, prioritizing pillars and conditions. In addition, a factor in the emergence of a car financing dispute at BPSK is the existence of a breach of contract or breach of contract. Mediation in Islamic legal perspective car financing at the Consumer Dispute Resolution Agency (BPSK) in Mataram City, originated from the number of public complaints related to the loss experienced by consumers due to the development of consumer financing systems that can provide convenience for consumers in meeting their special needs $\neg$ its needs like a motorized vehicle, in this case, a car. BPSK Mataram City has the duty and authority to carry out the handling and settlement of consumer disputes, by way of conciliation, mediation or arbitration, supervising the inclusion of standard clauses, and receiving complaints both written and unwritten from consumers about violations of consumer protection. The purpose of this research is to provide education and illustration related to mediation in car financing at BPSK Mataram City. Explain the causes of disputes at BPSK. And explain the mediation in car financing in BPSK Mataram City from the perspective of Islamic law. The method used is qualitative with a type of case approach, which means this approach is carried out by examining cases related to the issue being faced and has become a decision that has permanent legal force.
\end{abstract}

Keywords: mediation, car financing, consumer dispute settlement agency, Islamic law 
Abstrak: Tata cara pelaksanaan penyelesaian sengketa mediasi dalam pembiayaan mobil menurut hukum Islam dan Hukum Positif sama sama mengutamakan konsep keadilan, namun di BPSK tahapannya ada 3, yaitu permohonan, persidangan dan putusan. Sedangkan dalam konsep hukum Islam mengutamakan rukun dan syarat. Selain itu faktor dari timbulnya sengketa pembiayaan mobil di BPSK yaitu adanya cidera janji atau wanprestasi. Mediasi dalam pembiayaan mobil perspektif hukum Islam di Badan Penyelesaian Sengketa Konsumen (BPSK) Kota Mataram, berawal dari banyaknya keluhan-keluhan masyarakat terkait timbulnya kerugian yang dialami konsumen akibat berkembangnya sistem pembiayaan konsumen yang dapat memberikan kemudahan bagi konsumen dalam memenuhi kebutuhan hidupnya khususnya kebutuhan seperti kendaraan bermotor yang dalam hal ini mobil. BPSK Kota Mataram memiliki tugas dan wewenang melaksanakan penanganan dan penyelesaian sengketa konsumen, dengan cara konsiliasi, mediasi atau arbitrase, melakukan pengawasan pencantuman klausula baku, dan menerima pengaduan baik tertulis maupun tidak tertulis dari konsumen tentang terjadinya pelanggaran terhadap perlindungan konsumen. Tujuan dari penelitian ini untuk memberi edukasi dan gambaran terkait mediasi dalam pembiayaan mobil di BPSK Kota Mataram. Menjelaskan faktor penyebab timbulnya sengketa di BPSK. Dan menjelaskan mediasi dalam pembiayaan mobil di BPSK Kota Mataram perspektif hukum Islam. Metode yang digunakan yaitu kualitatif dengan jenis pendekatan kasus (case approach), yang artinya pendekatan ini dilakukan dengan cara menelaah kasus-kasus terkait dengan isu yang sedang dihadapi, dan telah menjadi putusan yang mempunyai kekuatan hukum tetap.

Kata Kunci: mediasi, pembiayaan mobil, badan penyelesaian sengketa konsumen, hukum Islam 


\section{Pendahuluan}

Manusia dalam menjalani hidup, senantiasa manusia menghadapi sejumlah tantangan dan kepentingan yang berbeda-beda satu sama lain. Akibatnya tidak bisa dihindari munculnya perbedaan dan pertentangan yang terjadi dalam kehidupan seharihari. Keragaman, perbedaan pandangan dan kepentingan merupakan potensi konflik. ${ }^{1}$ Pencarian pola penyelesaian sengketa atas konflik yang terjadi terus dilakukan manusia, dalam rangka memenuhi keinginan fitrahnya untuk hidup damai, adil dan sejahtera. Disisi lain, dalam memenuhi kebutuhan ekonominya, setiap individu mungkin akan menghadapi sengketa tentang hak dan kewajibannya yang berkaitan dengan nilai-nilai keadilan. Oleh karena itu, hukum memberikan alternative jalan keluar untuk menyelesaikan sengketa tersebut seperti misalnya melalui jalur arbitrase, negosiasi, konsiliasi, dan litigasi. $^{2}$

Secara konvensional, penyelesaian sengketa diselesaikan melalui proses litigasi (melalui pengadilan), dimana posisi para pihak berlawanan satu dengan yang lainnya dan proses ini akan memakan waktu yang lama. Sistem peradilan dinilai terlalu bertele-tele, membutuhkan waktu yang lama, dan tidak efisien.Selain itu, putusan pengadilan justru tidak memuaskan para pihak. ${ }^{3}$

Sehingga dalam penyelesaian sengketa terhadap suatu konflik terdapat solusi lain yaitu melalui nonlitigasi (di luar pengadilan), alternatif ini didasarkan atas kata sepakat (konsensus) yang dilakukan oleh para pihak yang bersengketa baik tanpa bantuan pihak ketiga netral ataupun dengan bantuan pihak ketiga netral. ${ }^{4}$ Alternative Dispute Resolution (ADR) juga merupakan lembaga penyelesaian sengketa atau beda pendapat melalui prosedur yang disepakati para pihak, yaitu penyelesaian di luar pengadilan dengan cara konsultasi, negosiasi, mediasi, konsiliasi atau penilaian ahli-ahli . Menurut Undang-Undang Nomor 30 Tahun 1999, Alternative Dispute Resolution adalah suatu pranata penyelesaian sengketa di luar pengadilan berdasarkan kesepakatan para pihak dengan mengesampingkan penyelesaian sengketa secara litigasi di pengadilan. Penyelesaian sengketa di luar pengadilan tersebut bukan suatu yang harus dilakukan atau dijalan terlebih dahulu. Dalam hal mediasi sebagai merupakan salah satu Alternative Dispute Resolution, maka mediasi tersebut termasuk ke dalam out of court settlement dan tidak merupakan kewajiban untuk dijalankan terlebih dahulu pada saat terjadi sengketa.

\footnotetext{
${ }^{1}$ Syahrizal Abbas, Mediasi dalam Hukum Syariah Hukum Adat dan Hukum Nasional (Jakarta: Kencana, 2011), hlm. 119.

${ }^{2}$ Jonker Sihombing, Peran dan Aspek Hukum dalam Pembangunan Ekonomi (Bandung: P.T. Alumni, 2010), hlm. 23.

3 Nurnaningsih Amriani, Mediasi Alternatif Penyelesaian Sengketa Perdata di Pengadilan (Jakarta: Rajawali Pers, 2012), hlm. 4.

${ }^{4}$ Rachmadi Usman, Mediasi di Pengadilan dalam Teori dan Praktik (Jakarta: Sinar Grafika, 2012), hlm. 2.
} 
Dalam hal ini mediasi sebagai out of court settlement merupakan salah satu pilihan bagi para pihak. ${ }^{5}$

Senada dengan hal di atas, maka pola penyelesaian sengketa melalui perdamaian tidak hanya berlaku umum, akan tetapi ditegaskan pula dalam konsep hukum Islam sebagaimana tercantum dalam Al-Qur'an surah al-Hujurat (49): 9-10.

Dan kalau ada dua golongan dari mereka yang beriman itu berperang hendaklah kamu damaikan antara keduanya tapi kalau yang satu melanggar perjanjian terhadap yang lain, hendaklah yang melanggar perjanjian itu kamu perangi sampai surut kembali pada perintah Allah. Kalau dia telah surut, damaikanlah antara keduanya menurut keadilan, dan hendaklah kamu berlaku adil. Sesungguhnya Allah mencintai orang-orang yang berlaku adil. Orang-orang beriman itu sesungguhnya bersaudara. Sebab itu damaikanlah (perbaikilah hubungan) antara kedua saudaramu itu dan takutlah terhadap Allah, supaya kamu mendapat rahmat. ${ }^{6}$

Esensi dari ayat ini mendukung konsep mediasi atau arbitrase dalam penyelesaian sengketa secara "fair" dengan intervensi pihak ketiga. Misi Islam dalam ayat ini adalah menghindari agresi, dan setiap muslim wajib menyelesaikan konflik dengan cara damai. Mereka diharuskan melakukan rekonsiliasi dengan setiap pihak, karena rekonsiliasi adalah jalan terbaik dalam penyelesaian konflik. Singkatnya, bahwa Islam menghindari adanya agresi dan tindakan kekerasan dalam penyelesaian sengketa. Islam menawarkan pendekatan damai dan non-kekerasan, melalui identifikasi sejumlah problema dan akar penyebab terjadinya konflik. Hal ini dapat dilakukan sebagai salah satu strategi penyelesaian konflik.?

Proses penyelesaian sengketa berdasarkan pola mediasi menjadi anjuran dalam konsep hukum Islam sebagaimana tercantum dalam Al-Qur'an. Pola penyelesaian sengketa ini pernah di praktikkan oleh Nabi Muhammad saw. baik sebelum ia menjadi rasul maupun sesudah menjadi rasul, hal ini dapat di cermati dalam peristiwa Perjanjian Hudaibiyah. Jika dianalisis tindakan Nabi Muhammad dalam Perjanjian Hudaibiyah dapat dipetik beberapa prinsip mediasi antara lain; sikap negosiasi, sikap kompromi take and give, memosisikan sama para pihak, dan menghargai kesepakatan. Dalam peristiwa perjanjian tersebut Nabi Muhammad telah berusaha meyakinkan kafir Quraisy agar bersedia duduk satu meja dengan kaum muslimin, yang sebelumnya adalah dua kelompok yang selalu bertikai. Dalam proses mediasi, kemampuan meyakinkan para pihak yang bersengketa untuk bersedia duduk satu meja merupakan langkah yang menentukan keberhasilan proses mediasi selanjutnya. ${ }^{8}$

${ }^{5}$ Mia Hadiati dan Mariske Myeke Tampi, "Efektivitas Mediasi Dalam Penyelesaian Sengketa Konsumen Oleh Badan Penyelesaian Sengketa Konsumen (BPSK) Di D.K.I Jakarta", Jurnal Hukum Prioris, Vol. 6, No. 1, Tahun 2017, hlm. 65.

${ }^{6}$ Kementerian Agama RI, Al-Qur'an dan Terjemahnya (Bandung: Fokusmedia, 2010), hlm. 516.

${ }^{7}$ Syahrizal, Mediasi dalam, hlm. 137.

${ }^{8}$ Syahrizal, hlm. 171. 
Merujuk pada uraian diatas, Pemerintah Kota Mataram dalam upaya memberikan perlindungan kepada warga masyarakatnya harus melakukan strategi. Salah satunya membentuk suatu badan yang bisa menampung keluhan-keluhan masyarakat sebagai konsumen. Badan Penyelesaian Sengketa Konsumen (BPSK) Kota Mataram memiliki tugas dan wewenang melaksanakan penanganan dan penyelesaian sengketa konsumen, dengan cara konsiliasi, mediasi atau arbitrase, melakukan pengawasan pencantuman klausula baku, dan menerima pengaduan baik tertulis maupun tidak tertulis dari konsumen tentang terjadinya pelanggaran terhadap perlindungan konsumen, ketentuan tersebut tetap mengacu pada Keputusan Menteri Perindustrian dan Perdagangan Republik Indonesia No.350/MPP/KEP/12/2001 tentang tugas dan wewenangnya. Umumnya sengketa yang seringkali ditangani di BPSK Kota Mataram ialah mengenai pembiayaan konsumen. Pembiayaan konsumen merupakan kegiatan pembiayaan dalam bentuk dana untuk pengadaan barang berdasarkan kebutuhan konsumen dengan sistem pembayaran angsuran atau berkala oleh konsumen. ${ }^{9}$

Pada dasarnya pembiayaan tidak hanya menyangkut barang-barang industri berat saja, tetapi juga masuk kepada kendaraan bermotor dan perumahan. Saat ini, banyak lembaga pembiayaan menyelenggarakan pembiayaan bagi konsumen (consumer finance), sewa guna usaha (leasing) dan lain sebagainya. Pada umumnya mereka menggunakan tata cara perjanjian yang mengikutkan adanya (jaminan fidusia) ${ }^{10}$ bagi objek benda jaminan fidusia. Dalam hal ini lembaga pembiayaan menyediakan barang bergerak yang diminta konsumen (semisal motor atau mobil) kemudian diatas namakan konsumen sebagai (debitur) (penerima kredit atau pinjaman). Konsekuensinya konsumen menyerahkan kepada pelaku usaha dalam hal ini sebagai (kreditur) (pemberi kredit) secara fidusia. Artinya konsumen sebagai pemilik atas nama barang menjadi pemberi fidusia kepada pelaku usaha (kreditur) yang dalam posisi sebagai penerima fidusia. Praktek sederhana dalam jaminan fidusia adalah konsumen (debitur) atau pihak yang punya barang mengajukan pembiayaan kepada pelaku usaha (kreditur), lalu kedua belah pihak sama-sama sepakat menggunakan jaminan fidusia terhadap benda milik debitur dan dibuatkan akta notaris lalu didaftarkan ke Kantor Pendaftaran Fidusia. Kreditur sebagai penerima fidusia akan mendapat sertifikat fidusia, dan salinanya akan diberikan kepada (debitur). Dengan mendapat sertifikat jaminan fidusia maka pelaku usaha (kreditur) atau penerima fidusia serta merta mempunyai hak eksekusi langsung (parate eksekusi) akan tetapi hak eksekusi tersebut tidak serta-merta dilakukan begitu saja, melainkan harus tunduk dan taat pada peraturan perundang-undangan yang berlaku. ${ }^{11}$

\footnotetext{
${ }^{9}$ Sunaryo, Hukum Lembaga Pembiayaan (Jakarta: Sinar Grafika, 2014), hlm. 96.

${ }^{10}$ Jaminan fidusia adalah hak jaminan atas benda bergerak baik yag berwujud maupun yang tidak berwujud dan benda tidak bergerak khususnya bangunan yang tidak dapat dibebani hak tanggungan sebagaimana yang dimaksud dalam Undang-undang No. 4 Tahun 1996 tentang Hak Taggungan yang tetap berada dalam penguasaan pemberi fidusia, sebagai agunan bagi pelunasan utang tertentu, yang memberikan kedudukan yang diutamakan kepada penerima fidusia terhadap kreditur lainnya.

${ }^{11}$ Nahrowi, "Permasalahan Hukum Pembiayaan Leasing di Indonesia", Jurnal Cita Hukum UIN Syarif Hidayatullah, No. 1, Vol. 1, Juni, 2013, hlm. 35.
} 
Namun, dalam fakta persidangan tidak jarang ditemukan beberapa pelaku usaha yang pada saat melakukan eksekusi terhadap objek jaminan (baik kendaraan roda empat maupun roda dua) tidak dilaksanakan sesuai dengan prosedur, yang artinya bahwa pelaku usaha dalam melakukan eksekusi terhadap objek jaminan tidak mengikuti peraturan perundangundangan yang berlaku, seperti misalnya tidak memberikan somasi (surat peringatan) terlebih dahulu kepada konsumen, ada juga pelaku usaha yang melakukan eksekusi tetapi tidak memiliki jaminan fidusia terhadap objek jaminan. Selain itu, ada juga pelaku usaha yang tidak memberikan BPKB kepada konsumen meskipun seluruh angsuran sudah dilunasi, tentunya hal ini dapat merugikan konsumen. Sehingga ketika konsumen dirugikan maka BPSK diharapkan dapat menjadi wadah dalam membela hak-hak konsumen. ${ }^{12}$

Penyelesaian sengketa di Badan Penyelesaian Sengketa Konsumen (BPSK) Kota Mataram tidak terlepas dari mekanisme penyelesaian sebagaimana di atur dalam ketentuan Undang-undang Nomor 8 Tahun 1999 tentang Perlindungan Konsumen yang didalamnya secara tegas memuat tentang penyelesaian dengan perdamaian. Akan tetapi, apabila perdamaian tidak tercapai maka BPSK Kota Mataram akan merekomendasikan penyelesaian sengketa tersebut ke Pihak Kepolisian. ${ }^{13}$

\section{Metodologi}

Sehubungan dengan upaya memperoleh data dan pengetahuan tentang Mediasi Dalam Pembiayaan Mobil Perspektif Hukum Islam di BPSK Kota Mataram, pendekatan yang digunakan yaitu yuridis empiris. Metode yang digunakan deskriptif. ${ }^{14}$ Jenis studi kasus (case approach) yang artinya dilakukan dengan cara menelaah kasus-kasus terkait dengan isu yang sedang dihadapi, dan telah menjadi putusan yang mempunyai kekuatan hukum tetap ${ }^{15}$. Selanjutnya sumber data diambil melalui Sumber data primer, yaitu data yang dikumpulkan dari situasi aktual ketika peristiwa terjadi. ${ }^{16}$ Dalam penelitian ini yang menjadi sumber data primer ialah, Responden adalah sejumlah orang yang memberikan respon atau tanggapan terhadap apa yang diminta atau ditentukan oleh peneliti. Dalam penelitian ini yang menjadi responden yaitu ketua, sekertariat, anggota BPSK Kota Mataram, Konsumen dan Pelaku Usaha. Sumber data sekunder, merupakan data yang dikumpulkan melalui tangan kedua atau dari sumber-sumber lain yang telah tersedia sebelum penelitian dilakukan. ${ }^{17}$ Berdasarkan uraian tersebut maka penelitian ini menggunakan sumber data sekunder, yaitu buku, jurnal, skripsi dan artikel-artikel yang berkaitan dengan judul penelitian ini.

${ }^{12}$ Observasi di kantor Badan Penyelesaian Sengketa Konsumen (BPSK) Kota Mataram, Mataram, 13 November 2017.

${ }^{13} \mathrm{lbid}$

${ }^{14}$ Nurul Zuriah, Metodologi Penelitian Sosial dan Pendidikan Teori-Aplikasi (Jakarta: PT. Bumi Aksara, 2006), hlm. 92.

${ }^{15}$ Amirudin dan Zainal Asikin, Pengantar Metode Penelitian Hukum (Jakarta: Rajawali Pers, Cet. 9, 2016), hlm. 165.

${ }^{16}$ Ulber Silalahi, Metode Penelitian Sosial (Bandung: PT Refika Aditama, 2010), hlm. 289.

${ }^{17}$ Ulber Silalahi, hlm. 291. 
Teknik pengumpulan data yang dilakukan ialah dengan cara wawancara dan observasi. Wawancara dan Observasi dilakukan terhadap teknik atau proses mediasi, intensitas pengaduan konsumen mengenai pembiayaan, dan alternatif penyelesaian sengketa antara konsumen dan pelaku usaha. Observasi dan wawancara, diuraikan sebagai berikut. Wawancara merupakan percakapan yang berlangsung secara sistematis dan terorganisasi yang dilakukan oleh peneliti sebagai pewawancara (interviewer) dengan sejumlah orang sebagai responden, misalnya dengan ketua, sekertariat, anggota BPSK Kota Mataram, konsumen dan pelaku usaha, sebagai pihak-pihak yang diwawancarai untuk mendapatkan sejumlah informasi yang berhubungan dengan masalah yang diteliti. ${ }^{18}$ Observasi diartikan sebagai pengamatan dan pencatatan secara sistematis terhadap gejala yang tampak pada objek penelitian. Dimana pengamatan dan pencatatan ini dilakukan terhadap objek di tempat terjadi atau berlangsungnya peristiwa. ${ }^{19}$

\section{Praktik Mediasi Pembiayaan Mobil di Badan Penyelesaian Sengketa Konsumen (BPSK) Kota Mataram}

Badan Penyelesaian Sengketa Konsumen (BPSK) dalam upaya penyelesaian sengketa konsumen, dilakukan dengan cara mediasi, konsiliasi, atau arbitrase. Akan tetapi, tata cara penyelenggaraannya di atur tersendiri dalam keputusan menteri perindustrian dan perdagangan. Penyelesaian sengketa yang dicapai melalui mediasi atau konsiliasi atau arbitrase dibuat dalam perjanjian tertulis dan dikuatkan dengan putusan majelis BPSK. Sifat kesepakatan ini adalah final dan mengikat. ${ }^{20}$ Namun, mediasi merupakan cara penyelesaian sengketa yang seringkali menjadi pilihan bagi para pihak. Istilah mediasi sebagaimana dalam ketentuan Pasal 1 Ayat 10 Kepmenperindag Nomor 350/MPP/Kep/12/2001 disebutkan bahwa mediasi adalah proses penyelesaian sengketa konsumen di luar pengadilan dengan perantara BPSK sebagai penasihat dan penyelesaiannya diserahkan kepada para pihak. Artinya, mediasi merupakan suatu proses penyelesaian sengketa dengan melibatkan pihak ketiga yang netral agar bisa membantu para pihak yang sedang bersengketa untuk dapat memecahkan masalah tersebut ${ }^{21}$.

Oleh karena itu dalam proses mediasi mediator dituntut untuk mampu berperan dalam $^{22}$ : a. Mendekatkan persamaan kepentingan dan meminimalkan perbedaan kepentingan; b. Menciptakan pertemuan yang kondusif, akrab dan terarah (fokus) pada substansi masalah; c. Tidak mempromosikan diri sebagai orang yang memutuskan dan tidak menilai

\footnotetext{
${ }^{18}$ Ulber Silalahi, hlm. 312.

${ }^{19}$ Nurul Zuriah, hlm. 173 .

${ }^{20}$ Sophar Maru Hutagalung, Praktik Peradilan Perdata dan Alternatif Penyelesaian Sengketa (Jakarta: Sinar Grafika, 2012), hlm. 331.

${ }^{21}$ Intan Nur Rahmawati dan Rukiyah Lubis, Win-Win Solution Sengketa Konsumen (Yogyakarta: Medpress Digital, Cet. 1, 2014), hlm. 76.

${ }^{22}$ Candra Irawan, Aspek Hukum dan Mekanisme Penyelesaian Sengketa di Luar Pengadilan (Alternative Dispute Resolution) (Bandung: Mandar Maju, 2010), hlm. 44.
} 
benar atau salah; c. Mendiagnosa substansi masalah mengidentifikasi masalah dan kemungkinan solusi yang dapat diterima oleh para pihak; d. Menawarkan usulan atau pilihan yang dapat diterima oleh para pihak; e. Menawarkan usulan atau pilihan pemecahan masalah kepada para pihak; f. Turut membantu pelaksanaan akta kompromi yang dihasilkan.

Di sisi lain, proses penyelesaian sengketa dengan cara mediasi, terdapat beberapa ketentuan-ketentuan, sebagai berikut ${ }^{23}, 1$. Mediasi dipimpin oleh aparat dinas yang berperan sebagai mediator dan dibantu oleh notulis; 2 . Mediator menyampaikan tata tertib mediasi yang perlu menjadu perhatian dan dipatuhi oleh para pihak selama berlangsungnya mediasi; 3. Mediator meyampaikan prinsip-prinsip penanganan dalam rangka penyelesaian sengketa konsumen kepada para pihak; 4. Mediator menyampaikan hak dan kewajiban para pihak sebagaimana ditur dalam ketentuan UU Nomor 8 Tahun 1999 tentang Perlindungan Konsumen; 5 . Mediator memberikan kesempatan yang seimbang kepada konsumen dan pelaku usaha secara bergantian untuk menyampaikan masalahnya dan harapan-harapan yang diinginkan; 6 . Notulis melakukan pencatatan selama berlangsungnya mediasi yang dituangkan dalam bentuk berita acara mediasi; 7. Mediator sedapat mungkian harus mengarahkan para pihak untuk menyelesaikan sengketa konsumen secara musyawarah dan kekeluargaan; 8. Dalam hal diperoleh kesepakatan penyelesaian oleh para pihak, hasil kesepakatan dibuat dalam berita acara penyelesaian sengketa konsumen dan ditandatangani oleh para pihak, mediator dan para saksi; 9 . Dalam hal pelaku usaha belum dapat menerima tuntutan konsumen, mediator memeberikan: a) Kesempatan paling lama lima hari kerja untuk melengkapi bukti sanggahan terhadap tuntutan konsumen; b) Mediator menetapkan waktu pelaksanaan acara mediasi lanjutan; 10. Dalam hal tidak tercapai kesepakatan penyelesaian sengketa diantara para pihakk, maka pihak mediator memberikan alternative penyelesaian sengketa melalui pengadilan negeri setempat; 11. Dalam hal telah di tandatangani berita acara penyelesaian sengketa konsumen oleh para pihak, maka pengaduan dinyatakan selesai. Penanganan mediasi berlangsung selama 12 hari kerja.

BPSK sebagai lembaga yang memiliki kewenagan dalam penanganan sengketa antara konsumen dna pelaku usaha, adapaun kasus yang seringkali diadukan oleh para pihak terkeit dengan pembiayaan konsumen. Pembiayaan konsumen merupakan badan usaha yang melakukan kegiatan pembiayaan untuk pengadaan barang berdasarkan kebutuhan konsumen dengan sistem pembayaran angsuran atau berkala oleh konsumen. Timbulnya jenis pembiayaan konsumen ini dipengaruhi oleh kemajuan di bidang teknologi sehingga telah memacu perusahaan untuk menghasilkan produk yang semakin canggih dan beragam. Kelebihan-kelebihan atas suatu produk terbaru mendorong masyarakat (konsumen) tergiur untuk memilikinya meskipun barangkali secara finansial dana untuk membelinya tidak

${ }^{23}$ Abdul Atsar dan ani Apriani, Buku Ajar Hukum Perlindungan Konsumen (Yogyakarta: Deepublish, 2019), hlm. 92. 
mencukupi. Bagi masyarakat kelas menengah ke bawah yang berpenghasilan rendah, hal ini tentu merupakan suatu problem tersendiri. Kondisi inilah yang antara lain menyebabkan tumbuh dan berkembangnya lembaga pembiayaan konsumen sebagai salah satu sumber pembiayaan alternatif untuk memenuhi kebutuhan konsumen atas barang-barang konsumtif yang dibutuhkannya seperti, rumah, mobil, televisi, radio, tape recorder, lemari es, tempat tidur, sepeda motor bahkan juga kebutuhan pokok sehari-hari. Melalui pembiayaan konsumen, masyarakat yang tadinya kesulitan untuk membeli barang secara tunai, akan dapat teratasi dengan mudah dan cepat. Kemudahan yang diberikan oleh lembaga pembiayaan konsumen melebihi kemudahan yang diberikan oleh bank. Lembaga pembiayaan konsumen memberikan kemudahan, keringanan, pelayanan yang cepat, waktu yang singkat, prosedur yang tidak birokratis dan tidak berbelit-belit. Kondisi tersebut sangat disukai oleh masyarakat, dan membawa suatu resiko yaitu dikemudian hari munculnya sengketa baik dari pelaku usaha maupun dari konsumen ${ }^{24}$.

Oleh karena itu, berdasarkan hasil penelitian yang dilakukan oleh peneliti di BPSK Kota Mataram umumnya penyelesaian sengketa konsumen menggunakan tiga cara yaitu penyelesaian dengan konsiliasi, penyelesaian dengan mediasi, dan penyelesaian dengan arbitrase. Dalam praktiknya, BPSK Kota Mataram dalam menangani setiap sengketa yang dilaporkan oleh konsumen menimbulkan pro dan kontra, karena keinginan konsumen dengan pelaku usaha seringkali bertentangan sehingga majelis BPSK terlebih dahulu melakukan pra sidang dalam proses beracaranya. Hal tersebut dilakukan guna memberikan ruang kepada para pihak untuk menjelaskan apa yang menjadi pokok permasalahan, apa yang menjadi tuntutan para pihak dan untuk menentukan cara penyelesaiannya.

Hasil penelitian menunjukan bahwa Mediasi di Badan Penyelesaian Sengketa Konsumen dapat diuraikan sebagai berikut:

Uraian Kasus No. 13/BPSK/III/2017 antara Bapak Suhardi (pemohon) dengan PT. Amanah Finance (termohon).

Pihak pemohon menerima over alih kredit dari Sahli Pandi selaku konsumen yang menandatangani perjanjian. Dengan mobil Pick Up Carry sebagai objek jaminan dan di fasilitasi oleh lembaga pembiayaan PT. Amanah Finance dengan kontrak perjanjian selama 3 tahun (36 kali angsuran). Pada tanggal 1 September 2016, pemohon telah melunasi seluruh angsuran dan termohon menjanjikan BPKB keluar setelah satu bulan pelunasan, akan tetapi sampai dengan 2017 BPKB tersebut tidak dikeluarkan dengan alasan masih berada di kantor pusat Makassar. Dalam pelaporannya ke BPSK Kota Mataram, pemohon mengajukan tuntutan ganti rugi berupa pemberian BPKB mobil. Pemohon dan Termohon sepakat menyelesaiakan sengketanya dengan cara mediasi.

Praktik mediasi yang digunakan dalam penyelesaian sengketa kasus di atas, maka dalam fakta persidangan di BPSK Kota Mataram, Suhardi menyatakan:

${ }^{24}$ Endang Prasetyawati, "Konsep Hukum Pembiayaan Konsumen Di Masa Yang Akan Datang", Yustisia Vol. 2 No.2 Mei - Agustus 2013, hlm. 31. 
Penyelesaian sengketa dengan cara mediasi di BPSK Kota Mataram sudah efektif, bahkan Suhardi merasa sangat terbantu dengan adanya penyelesaian sengketa yang mengutamakan musyawarah untuk mencapai perdamaian antara dirinya dengan pihak PT. Amanah Finance. Lebih jauh Suhardi menjelaskan bahwa majelis BPSK telah melakukan proses penyelesaian dengan cara mediasi yang adil dan tidak memihak antara satu sama lain. Suhardi menambahkan bahwa dirinya diberikan kebebasan untuk bernegosiasi dengan pihak Amanah Finance. ${ }^{25}$

Maka, penyelesaian sengketa dengan cara mediasi terhadap kasus di atas telah sesuai dengan Pasal 30 Keputusan Menteri Perindustrian dan Perdagangan No.35o/ MPP/Kep/12/2001, membahas mengenai tata cara penyelesaian sengketa dengan cara mediasi.

Uraian kasus No. 24/BPSK/V/2017 antara Ibu Yuni Maryuzim (pemohon) dengan PT. Mandiri Tunas Finance (termohon).

Bahwa pada tanggal 8 Desember 2017 pemohon mengajukan kredit 1 unit mobil daihatsu ayla di PT. Mandiri Tunas Finance (termohon) dengan DP sejumlah Rp 25.000.000 dan angsuran Rp 2.779.000 /bulan dalam jangka waktu kontrak selama 60 bulan. Dengan berjalannya waktu keadaan ekonomi pemohon tidak memungkinkkan untuk dapat membayar angsuran sehingga terlambat pembayaran angsuran selama 3 bulan, namun pemohon telah melakukan i'tikad baik dengan tetap membayar sampai dengan /3 mei 2018. Pada akhirnya mobil tersebut di tarik oleh termohon. Sehingga pemohon melakukan pengaduan ke BPSK Kota Mataram dengan jenis tuntutan ganti rugi berupa pengambilan kembali mobil yang telah di cabut dan melanjutkan kredit. Dalam penyelesaian sengketa di BPSK Kota Mataram pemohon dan termohon sepakat dengan cara mediasi.

Berkaitan dengan praktik mediasi dalam fakta persidangan di BPSK Kota Mataram, Yuni Maryuzim menyatakan:

Praktik mediasi di BPSK Kota Mataram sangat menjunjung tinggi aspek musyawarah dan kekeluargaan karena dalam menyelesaikan kasus Yuni sangat merasa terbantu dengan penyelesaian sengketa konsumen yang di lakukan melalui BPSK, sehingga ia merasa terbantu. ${ }^{26}$

Aspek musyawarah dan kekeluargaan merupakan prinsip dasar dalam penyelesaian sengketa yang harus dijunjung tinggi dan prinsip dasar ini menjadi karakteristik dari BPSK, yaitu murah, cepat dan sederhana. Murah diartikan bahwa penyelesaian sengketa di BPSK tidak dipungut biaya. Cepat berkaitan dengan waktu dalam penyelesaian snegketa di BPSK selambat-lambatnya dalam waktu 21 hari kerja sehingga terbit putusan BPSK. Sederhana diartikan bahwa majelis BPSK, berperan untuk menyelesaian sengketa dengan cara damai, musyawarah dan kekeluargaan. Tentu hal ini senada dengan Pasal 39 Ayat 1 Keputusan Menteri Perindustrian dan Perdagangan No. 350/ MPP/Kep/12/2001 tentang Pelaksanaan Tugas dan Wewenang BPSK, berbunyi: "Putusan majelis didasarkan atas musyawarah untuk

\footnotetext{
${ }^{25}$ Suhardi, konsumen PT. Amanah Finance. Wawancara tanggal 13 Januari 2018, pukul 14.00 WITA.

${ }^{26}$ Yuni Maryuzim, konsumen PT. Mandiri Tunas Finance. Wawancara tanggal 12 November 2017, pukul 14.20 WITA.
} 
mencapai mufakat, namun jika setelah diusahakan dengan sungguh-sungguh tidak dapat mencapai mufakat, maka putusan diambil dengan suara terbanyak".

Praktik mediasi dalam kasus di atas dinilai baik dan sangat membantu peraturan serta teori yang ada, sehingga para majelis BPSK Kota Mataram dapat terus mempertahankan aspek musyawarah dan kekeluaragaan agar nantinya putusan yang dikeluarkan dapat menguntungkan kedua belah pihak.

Pertama. Penyelesaian sengketa konsumen dengan cara mediasi yang dilakukan di BPSK Kota Mataram dalam kasus pembiayaan mobil, Ahmad bin Talibok menyatakan:

Mediasi yang dilakukan di BPSK Kota Mataram, dalam kasus pembiayaan mobil sudah sangat luar biasa, karena sebagai pelaku usaha Ahmad merasa terbantu dalam menyelesaikan permasalahn konsumen. Ahmad menambahkan bahwa prosedur serta tata cara mediasi yang digunakan sesuai dengan apa yang tertera dalam UUPK, Keputusan Menteri Perindustrian dan Perdagangan serta teori-teori perlindungan konsumen. ${ }^{27}$

Kedua. Menurut Haerani selaku wakil ketua BPSK Kota Mataram, berkaitan dengan mediasi yang dilakukan oleh majelis BPSK, bahwa:

Proses penyelesaian sengketa di BPSK telah sesuai dengan tehnik dan prosedur, baik berdasarkan teori, Undang-undang No. 8 Tahun 1999 tentang Perlindungan Konsumen dan Keputusan Menteri Perindustrian dan Perdagangan 350/ MPP/Kep/12/ 2001 tentang Pelaksanaan Tugas dan Wewenang BPSK. Selanjutnya Haerani menambahkan bahwa pada umumnya prosedur penyelesaian sengketa konsumen melalui BPSK terdiri dari 3 (tiga) tahap, yaitu: Tahap Permohonan, dalam tahap permohonan BPSK Kota Mataram tetap mengacu pada Pasal 16 Kepmenperindang 350/MPP/Kep/12/2001. Konsumen dapat mengajukan pengaduan secara tertulis maupun lisan. ${ }^{28}$

Dari hasil wawancara di atas, peneliti dapat menarik kesimpulan bahwa mediasi yang dilakukan di BPSK Kota Mataram untuk menyelesaikan sengketa antara konsumen dan pelaku usaha dalam pembiayaan mobil, berjalan efektif dan sangat membantu para pihak menemukan jalan keluar terhadap sengketa yang terjadi. Namun tak jarang hasil putusan mediasi yang dikeluarkan oleh BPSK Kota Mataram justru tidak tercapai kesepakatan atau tidak menemukan jalan keluar. Selain itu prosedur serta tahapan-tahapan mediasi yang digunakan telah sesuai dengan hukum acara yang berlaku di BPSK Kota Mataram yaitu Keputusan Menteri Perindustrian dan Perdagangan No. 350/MPP/Kep/12/2001 Tentang Tugas dan Wewenang Badan Penyelesaian Sengketa Konsumen. Namun, terdapat beberapa aspek yang perlu ditingkatkan dan dibenahi yaitu adanya ruang bernegosiasi secara bebas bagi para pihak untuk menyampaikan tuntutannya, aspek musyawarah dan kekeluargaan lebih ditingkatkan lagi sehingga menghasilkan putusan yang adil dan sesuai dengan hukum acara BPSK Kota Mataram.

${ }^{27}$ Ahmad bin Talibok, pelaku usaha di PT. Astra Credit Companies (ACC). Wawancara tanggal 23 Januari 2018, pukul 11.40 WITA.

${ }^{28}$ Haerani, Ketua Badan Penyelesaian Sengketa Konsumen (BPSK) Kota Mataram. Wawancara tanggal 8 Februari 2018, pukul 17.00 WITA. 


\section{Faktor Penyebab Timbulnya Sengketa Antara Konsumen dan Pelaku Usaha dalam Pembiayaan Mobil di Badan Penyelesaian Sengketa Konsumen}

Kedudukan konsumen terhadap pelaku usaha yang seharusnya seimbang menjadi lemah karena rendahnya pengetahuan konsumen akan hak-haknya. Mengenai hak-hak konsumen terdapat dalam Pasal 5 Undang-undang No. 8 Tahun 1999 tentang Perlindungan Konsumen, namun dalam praktiknya seringkali terjadi pelanggaran terhadap hak-hak konsumen tersebut, yang kemudian berujung pada lahirnya sengketa antara konsumen dan pelaku usaha. Sebagaimana yang tercantum dalam Pasal 1 angka 8 Kepmenperindang No. 350/MPP/Kep/12/2001 tentang Pelaksanaan Tugas dan Wewenang Badan Penyelesaian Sengketa Konsumen adalah sengketa antara pelaku usaha dengan konsumen yang menuntut ganti rugi atas kerusakan, pencemaran dan/ atau yang menderita kerugian akibat mengkonsumsi barang dan/atau memanfaatkan jasa.

Berdasarkan hasil penelitian yang peneliti lakukan di BPSK Kota Mataram terkait dengan faktor penyebab timbulnya sengketa antara konsumen dan pelaku usaha dalam pembiayaan mobil sebagian besar diakibatkan karena adanya wanprestasi. Tetapi sebaliknya ketika debitur wanprestasi ${ }^{29}$, beberapa pelaku usaha juga melakukan perbuatan melawan hukum. Secara umum ada empat keadaan wanprestasi, yaitu: 1. Tidak memenuhi prestasi; 2. Terlambat memenuhi prestasi; 3. Memenuhi prestasi secara tidak baik; dan 4. Melakukan sesuatu yang menurut perjanjian tidak boleh dilakukannya. Adapun akibat hukum wanprestasi diantaranya: a. Debitur diharuskan membayar ganti rugi ${ }^{30} ;$ b. Kreditur dapat meminta pembatalan perjanjian melalui pengadilan ${ }^{31} ;$ c. Kreditur dapat meminta pemenuhan perjanjian atau pemenuhan perjanjian disertai ganti rugi dan pembatalan perjanjian dengan ganti rugi ${ }^{32}$. Sedangkan pengertian perbuatan melawan hukum tidak diatur dalam Kitab Undang-undang Hukum Perdata, yang berbunyi33: "Tiap Perbuatan yang melawan hukum dan membawa kerugian kepada orang lain, mewajibakn orang yang menimbulkan kerugian itu karena kesalahannya untuk mengganti kerugian tersebut".

Dari rumusan di atas dapat disimpulkan bahwa terdapat unsur-unsur, sebagai berikut: $^{34}$ (a). Adanya perbuatan melawan hukum yaitu dalam arti sempit perbuatan melanggar undang-undang dan lebih kuasnya melanggar hak orang lain, bertentangan dengan kewajiban hukum pelaku, bertentangan dengan kesusilaan, bertentangan dengan sikap kehati-hatian yang dianggap sepatutnya dalam masyarakat; (b). Adanya kesalahan; (c). Adanya kerugian; (d). Adanya hubungan sebab akibat antara kerugian dan perbuatan.

${ }^{29}$ Wanprestasi artinya tidak memenuhi kewajiban sebagaimana ditetapkan dalam perikatan atau perjanjian.

${ }^{30}$ Pasal 1243 KUH Perdata

${ }^{31}$ Pasal 1266 KUH Perdata

${ }^{32}$ Pasal 1267 KUH Perdata

${ }^{33}$ Pasal 1365 KUH Perdata

${ }^{34}$ Djaja S. Meliala, Perkembangan Hukum Perdata Tentang Benda dan Hukum Perikatan (Bandung: CV. Nuansa Aulia, 2007), hlm. 111. 
Berdasarkan Pasal tersebut ditentukan syarat-syarat untuk menuntut ganti kerugian karena perbuatan melawan hukum, jika kerugian timbul karena ada unsur kesalahan dari pelaku.

Berikut ini beberapa contoh wanprestasi dan perbuatan melawan hukum yang peneliti lakukan di lapangan, antara lain, perjanjian pembiayaan konsumen antara PT. Astra Credit Companies (ACC) Cabang Mataram dengan konsumen. Maka berdasarkan hasil wawancara dengan bapak Ahmad bin Talibok, selaku AR Management Head PT. ACC Cabang Mataram, Ahmad menyatakan:

Bahwa perjanjian yang ada di dalam perusahaan pembiayaan sifatnya perjanjian baku. Artinya perjanjian tersebut memang telah dibuat secara sepihak oleh perushaan pembiayaan. Perjanjian baku ini tidak hanya berlaku pada PT. ACC Finance, melainkan berlaku pula untuk semua lembaga pembiayaan lainnya. Ahmad menambahkan, sebelum isi perjanjian disepakati oleh pihak konsumen maka terlebih dahulu pihaknya menjelaskan point-point penting isi perjanjian, semisal mengenai jatuh tempo, denda, cara bayar, biaya administrasi dan bahkan konsumen diberikan photo copy perjanjian yang telah disepakati untuk dapat lebih lanjut di pahami. Selain itu, dalam akta perjanjian yang telah di buat oleh pelaku usaha maka dalam point akhir pihak pelaku usaha telah memberikan kesimpulan atas keseluruhan isi kontrak perjanjian, sehingga lebih mempermudah konsumen dalam memahami. Lebih jauh, beliau menyatakan faktor penyebab timbulnya sengketa konsumen ialah adanya over alih kredit, kredit macet (penunggakan pembayaran), cash flow, dan mobil di gadaikan. Namun secara umum dan seringkali terjadi sengketa mengenai over alih kredit yang menyebabkan kredit macet (penunggakan pembayaran yang dilakukan oleh konsumen). ${ }^{35}$

Sebagaimana dalam isi perjanjian baku yang telah di buat oleh pelaku usaha, kemudian disepakati oleh konsumen. Dalam isi perjanjian tersebut terdapat pasal yang menyatakan bahwa konsumen harus mengikuti dan mentaati isi perjanjian yang telah ditetapkan oleh pihak pelaku usaha. Sehingga apabila dikemudian hari terjadi wanprestasi yang dilakukan oleh konsumen, maka pihak pelaku usaha berhak meminta pemenuhan perjanjian atau pemenuhan perjanjian disertai ganti rugi dan pembatalan perjanjian dengan ganti rugi, hal ini sesuai dengan ketentuan Pasal 1267 KUH Perdata.

Namun, lain halnya dengan hasil penelitian yang peneliti lakukan di BPSK Kota Mataram, dalam perjanjian pembiayaan konsumen antara PT. ACC (Astra Credit Companies) Finance Cabang Mataram selaku pihak kedua dengan konsumen $(\mathrm{Hj}$. Muslihati selaku pemohon/pihak pertama dan Ahmad Rapi,i selaku turut termohon/pihak ketiga) dalam pengaduannya ke BPSK Kota Mataram dengan perkara No. og/BPSK/V/ $2016^{36}$ :

Kasus ini bermula ketika pemohon melakukan kesepakatan untuk malakukan over alih kredit dengan pihak ketiga (Ahmad Rapi,i) atas sepengetahuan dan persetujuan dari pihak perusahaan yang dibuktikan dengan pembayaran angsuran yang ditagihkan kepada

\footnotetext{
${ }^{35}$ Ahmad Bin Talibok. Wawancara tanggal 29 Januari 2018, pukul 11.40 WITA

${ }^{36}$ Dokumen Badan Penyelesaian Sengketa Konsumen (BPSK) Kota Mataram.
} 
pemohon/pihak pertama ( 3 kali angsuran telah dibayar), serta diserahkannya syarat dan biaya balik nama sebesar Rp. 1.700.000 kepada Norman selaku karyawan perusahaan, akan tetapi Norman tidak menyerahkan biaya balik nama tersebut kepada termohon sehingga secara administratif pemohon tidak tercatat sebagai konsumen pengganti dari turut termohon. Selanjutnya dalam pelaksanaan pembayaran angsuran, pihak pertama melakukan penunggakan selama 3 bulan yang berujung pada penarikan unit kendaraan tersebut. Pihak pertama sudah menunjukkan i'tikad baik dengan datang ke perusahaan untuk melunasi seluruh tunggakan senilai Rp. 137.000.000. Namun pihak perusahaan menjawab bahwa keputusan ada pada manajemen pusat dan memberikan jangka waktu pelunasan paling lama 1 (satu) bulan. Belum mencapai waktu 1 (satu) bulan, ketika pemohon datang melunasi tunggakan tersebut unit kendaraan sudah di lelang tanpa adanya pemberitahuan kepada pihak pertama dan pihak ketiga yang secara administratif masih tercatat sebagai konsumennya.

Berkaitan dengan kasus di atas, maka sebagaimana ketentuan mengenai lembaga pembiayaan disebutkan bahwa ${ }^{37}$, "Perusahaan pembiayaan yang melakukan pembiayaan konsumen untuk kendaraan bermotor dengan pembebanan jaminan fidusia wajib mendaftarkan jaminan fidusia dimaksud pada kantor pendaftaran fidusia, sesuai Undang-undang yang mengatur mengenai jaminan fidusia."

Jelas dalam ketentuan tersebut bahwa setiap objek jaminan fidusia maka harus didaftarakan terlebih dahulu ke kantor jaminan fidusia, kemudian kantor pendaftaran fidusia mengeluarkan sertifikat fidusia. Sehingga dalam Undang-Undang Jaminan Fidusia, dijelaskan ${ }^{38}$ : "Apabila debitur cidera janji, penerima fidusia mempunyai hak untuk menjual benda yang menjadi objek jaminan fidusia atas kekuasaannya sendiri".

Mengenai penjualan objek jaminan fidusia maka dijelaskan"39, "Pelaksanaan penjualan obejk jaminan fidusia dilakukan setelah lewat waktu 1 (satu) bulan sejak diberitahukan secara tertulis oleh pemberi dan penerima fidusia kepada pihak-pihak yang berkepentingan dan diumumkan sedikitnya dalam 2 (dua) surat kabar yang beredar di daerah yang bersangkutan".

Sehingga jelas bahwa hasil penelitian peneliti bertentangan dengan Undang-undang dengan melakukan perbuatan melawan hukum. Mengingat pihak pelaku usaha melakukan pelelangan objek jaminan fidusia sebelum waktu yang ditentukan serta tidak melakukan pemberitahuan atau mengumumkan melalui surat kabar sebagaimana aturan yang ada dalam Keputusan Menteri Perindustrian dan Perdagangan serta Peraturan Menteri Keuangan. Perjanjian pembiayaan konsumen antara PT. Otto Multiarta Cabang Mataram

\footnotetext{
${ }^{37}$ Pasal 1 Peraturan Menteri Keuangan No. 130/PMK.010/2012 tentang Pendaftaran Jaminan Fidusia bagi Perusahaan Pembiayaan yang Melakukan Pembiayaan Konsumen untuk Kendaraan Bermotor dengan Pembebanan Jaminan Fidusia.

${ }^{38}$ Pasal 15 Ayat 3 Undang-Undang Nomor 42 Tahun 1999 tentang Jaminan Fidusia.

39 Pasal 29 ayat 2 Undang-Undang Nomor 42 Tahun 1999 tentang Jaminan Fidusia.
} 
dengan konsumen. Maka berdasarkan hasil wawancara dengan bapak Yudi selaku kepala administrasi PT. Otto Multiarta Cabang Mataram, beliau menyatakan: ${ }^{4^{\circ}}$

Mengenai masalah kontrak perjanjian bahwa sebelum konsumen menandatangani kontrak perjanjian, perusahaan menyebeut kotrak perjanjian tersebut dengan summary product (ringkasan produk), dalam perjanjian ini segala sesuatu mengenai perjanjian tertera secara jelas dan rinci bahkan konsumen diberi untuk nantinya dibaca kemudian di pahami pointer-pointer penting dalam kontrak perjanjian. Berkaitan dengan penyebab timbulnya sengketa konsumen, seringkali konsumen melakukan gadai terhadap objek jaminan tanpa sepengetahuan pihak perusahaan serta over alih kredit credit yang dilakukan di bawah tangan tanpa melakukan konfirmasi kepada pelaku usaha, padahal ini telah diedukasi pihak pelaku usaha kepada konsumen bahwa tidak boleh dilakukan. Akan tetapi, pihak konsumen susah untuk dapat memahami ketentuan ini. Karena nantinya akan terkendala pada saat pengambilan BPKB (Bukti Pemilikan Kendaraan Bermotor).

Terhadap pengalihan yang dilakukan oleh debitur, dalam perjanjian pembiayaan konsumen antara PT. Otto Multiarta Finance dengan konsumen terdapat klausula yang menyatakan bahwa salah satu kewajiban dari debitur adalah tidak mengalihkan kendaraan kepada pihak lain. Ketentuan ini sesuai dengan Undang-Undang Jaminan Fidusia, sebagai berikut ${ }^{41}$ :

Pemberi fidusia dilarang mengalihkan, menggadaikan, atau menyewakan kepada pihak lain benda yang menjadi objek jaminan fidusia yang tidak merupakan benda persediaaan, kecuali dengan persetujuan tertulis terlebih dahulu dari penerima fidusia. Penerima fidusia tidak menanggung kewajiban atas akibat tindakan atau kelalaian pemberi fidusia baik yang timbul dari hubungan kontraktual atau yang timbul dari perbuatan melanggar hukum sehubungan dengan penggunaan dan pengalihan benda yang menjadi objek jaminan fidusia.

Mengacu pada ketentuan di atas jika hal tersebut terjadi, konsekuensianya kreditur secaara sepihak dapat memutus kontrak dan kreditur berhak untuk menyatakan hutang jatuh tempo dan menuntut pelunasan atau jika debitur tidak melunasi hutang, krediur berhak menuntut pengembalian atau mengambil kembali kendaraan dari debitur atau pemilik jaminan atau pihak lain dengan cara langsung mengambil dari tempat dimana kendaraan berada tanpa melalui juru sita pengadilan atau peringatan lainnya. Terlebih jika pengalihan yang dilakukan debitur tanpa sepengetahuan perusahaan. Sehingga hal tersebut dapat dikategorikan sebagai cidera janji/wanprestasi dimana debitur dalam keadaan melakukan sesuatu yang menurut perjanjian tidak boleh dilakukan.

Sama halnya dengan fakta yang peneliti dapatkan di BPSK Kota Mataram, dalam perjanjian pembiayaan konsumen antara PT. Otto Multiartha Finance Cabang Mataram

$4^{\circ}$ Yudi selaku pelaku usaha dari perusahaan pembiayaan Otto Finance. Wawancara tanggal 6 Desember 2018, pukul 15.30 WITA.

${ }^{41}$ Pasal 23 dan 24 Undang-Undang Nomor 24 Tahun 1999 tentang Jaminan Fidusia. 
selaku pihak kedua dengan konsumen ( $\mathrm{H}$. Saf'i Burhanuddin selaku pemohon/pihak pertama dan PT.Otto Multiartha Finance selaku termohon/pihak kedua) dalam pengaduannya ke BPSK Kota Mataram dengan perkara No. 37/BPSK/XII/201 $4^{42}$.

Kasus ini bermula ketika penggugat mengambil alih kredit satu unit mobil atas nama $\mathrm{H}$. Kahfi yang dibeli oleh $\mathrm{H}$. Saf'i Burhanuddin dari bapak Darwis yang menerima unit dari bapak Bambang Sugiarto dengan adanya fasilitas pembiayaan dari PT. Otto Multiartha Finance selaku tergugat. Berkaitan dengan over alih kredit tersebut maka hal ini telah diketahui oleh pihak tergugat, akan tetapi tidak di tindak lanjuti secara tertulis melainkan hanya secara lisan. Diketahui bahwa pihak penggugat telah melunasi seluruh angsusan pada buulan juli 2017, namun tergugat tidak dapat memberikan BPKB mobil dikarenakan bahwa penggugat bukan merupakan konsumen pihak tergugat yang bertanda tangan di kontrak perjanjian. Penggugat telah berusaha menghubungi bapak Darwis dan bapak Bambang namun tidak di respon sama sekali. Pada akhirnya penggugat melaporkan kasus ini ke BPSK Kota Mataram dengan tuntutan ganti rugi adanya pemberian BPKB mobil. Berkaitan dengan kasus tersebut maka, maka dijelaskann" ${ }^{43}$ "Pemberi fidusia dilarang mengalihkan, menggadaikan, atau menyewakan kepada pihak lain benda yang menjadi objek jaminan fidusia yang tidak merupakan benda persediaan, kecuali dengan persetujuan tertulis terlebih dahulu dari penerima fidusia"

Dari uraian di atas, tampak bahwa sengketa konsumen antara PT. Otto Multiartha Finance dengan konsumen yang diadukan ke BPSK Kota Mataram adalah terkait dengan over alih kredit yang dilakukan debitor tanpa sepengetahuan kreditor yang berakibat saat pengambilan BPKB debitor akan dipersulit. Karena aturan pengambilan BPKB harus dilakukan oleh debitor yang menandatangani kontrak dengan perusahaan. Selain itu maka over alih kredit juga telah melanggar ketentuan dalam Undang-undang jaminan fidusia. Dari hasil penelitian yang peneliti temukan di lapangan, bahwa penyebab timbulnya sengketa pembiayaan konsumen di BPSK Kota Mataram, ialah adanya wanprestasi dan perbuatan melawan hukum. wanprestasi seringkali timbul akibat tidak dipenuhinya perjanjian yang telah disepakati oleh para pihak baik konsumen ataupun pelaku usaha. Sedangkan perbuatan melawan hukum dalam kasus pembiayaan mobil seringkali dilakukan oleh pelaku usaha, dimana hal tersebut dilakukan akibat tidak adanya i'tikad baik dari pihak konsumen.

\section{Mediasi Pembiayaan Mobil Perspektif Hukum Islam di Badan Penyelesaian Sengketa Konsumen (BPSK) Kota Mataram}

Islam sebagai agama yang sangat menjunjung adanya perdamaian, hal tersebut sangatlah dianjurkan oleh Allah swt. sehingga tercantum dalam firman-Nya Al-Qur'an surat an-Nisa' (4): 114 .

\footnotetext{
$4^{42}$ Dokumen Badan Penyelesaian Sengketa Konsumen (BPSK) Kota Mataram.

${ }^{43}$ Pasal 23 ayat 2 Undang-undang No. 42 Tahun 1999 tentang Jaminan Fidusia.
} 


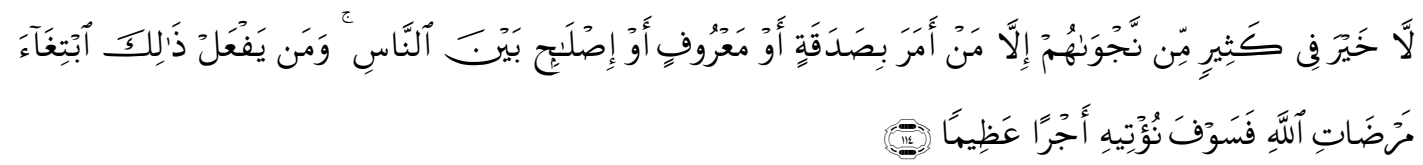

"Tidak ada kebaikan pada kebanyakan bisikan-bisikan mereka, kecuali bisikanbisikan dari orang yang menyuruh (manusia) memberi sedekah, atau berbuat ma'ruf, atau mengadakan perdamaian di antara manusia. Dan barangsiapa yang berbuat demikian karena mencari keredhaan Allah, maka kelak kami memberi kepadanya pahala yang besar".

Perdamaian (sulh) dapat dikembangkan untuk menjadi metode penyelesaian berbagai jenis sengketa, termasuk sengketa perdata dan bisnis sebagaimana ajaran Islam yang memerintahkan agar menyelesaikan setiap perselisihan yang terjadi antara manusia dengan cara perdamaian. Kemampuan menyelesaikan sengketa yang didasarkan atas nilai agama akan mampu melahirkan kekuatan dalam perdamaian, karena ajaran agama Islam memiliki nilai universal kemanusiaan. Sebagaimana yang dikemukakan oleh George E. Irani dan Nathan C. Funk, bahwa Al-Quran memiliki sejumlah prinsip dalam perdamaian yang nantinya dapat digunakan untuk menyelesaikan sengketa. Prinsip tersebut antara lain ${ }^{44}$ "1. Keadilan; 2. Kesamaan; 3. Universal dan martabat manusia; 4. Penguatan sosial dengan berbuat baik; 5 . Empati; dan 5. Menaruh perhatian terhadap orang lain".

Prinsip yang di ungkapkan oleh ilmuan tersebut di atas, bahwa pada dasarnya dalam penyelesaian sengketa baik berdasarkan hukum Islam ataupun hukum acara yang digunakan oleh BPSK Kota Mataram dari ke enam prinsip tersebut tidak secara keseluruhan diterapkan oleh BPSK. Sehingga hasil penelitian yang peneliti lakukan pada bab sebelumnya terdapat beberapa konsumen menyatakan bahwa mengenai keadilan pihak majelis BPSK Kota Mataram dinilai efektif, karena hasil mediasi antara konsumen dan pelaku usaha tercapai kesepakatan.

Prinsip keadilan ini di tegaskan pula oleh Allah swt. dalam firman-Nya Al-Qur'an surat an-Nisa' (4):58.

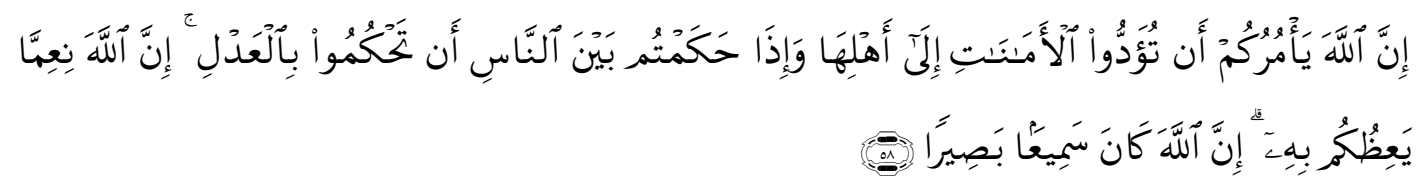

"Sesungguhnya Allah menyuruh kamu menyampaikan amanat kepada yang berhak menerimanya, dan (menyuruh kamu) apabila menetapkan hukum di antara manusia supaya kamu menetapkan dengan adil. Sesungguhnya Allah memberi pengajaran yang sebaik-baiknya kepadamu. Sesungguhnya Allah adalah Maha mendengar lagi Maha melihat".

${ }^{44}$ Syahrizal Abbas, hlm. 125 
Ayat di atas merupakan anjuran dari Allah swt. bahwa keadilan harus ditegakkan dalam segala hal terutama dalam hal menentukan hukum atau aturan. Sama halnya dalam melakukan penyelesaian sengketa maka, dianjurkan untuk seorang juru damai (mediator) berlaku adil dan tidak membedakan antara para pihak yang bersengketa. Mediasi (perdamaian) dalam penyelesaian sengketa tertumpu pembahasannya pada akad perdamaian yang mengakhiri sengketa kehartabendaan. Sengketa kehartabendaan muncul dari adanya para pihak atau salah satu pihak mengingkari atau tidak menjalankan kesepakatan yang tertuang dalam akad yang disepakati bersama. Bila salah satu atau kedua pihak yang terikat dalam kontrak itu tidak dapat dipenuhi kewajibannya, maka ia atau mereka menerima sanksi seperti yang sudah disepakati dalam akad dengan adanya keridhaan kedua belah pihak. ${ }^{45}$

Berdasarkan konsep teori tersebut dikatakan bahwa perdamaian dalam penyelesaian sengketa menekankan adanya akad yang dilakukan oleh para pihak, maka apabila dikemudian hari para pihak mengingkari perjanjian, maka berhak di sanksi sesuai dengan kesepakatan, sama halnya dalam penyelesaian sengketa yang dilakukan di BPSK Kota Mataram salah satu penyebab timbulnya sengketa dari para pihak ialah karena adanya cidera janji atau wanprestasi, ini berkaitan dengan tidak dijalankannya perjanjian yang telah disepakati di awal sehingga timbul sengketa antara konsumen dan pelaku usaha khusunya dalam pembiayaan mobil. Sehingga terdapat hal yang harus diperhatikan dalam menunaikan akad, yaitu menggambarkan kesungguhan kemauan dari pihak-pihak yang bersangkutan, tidak terpaksa dan tidak karena diancam atau ditakut-takuti oleh orang lain karena dalam tijarah harus saling rida. ${ }^{46}$

Konsep ridha (kerelaan) sebagaimana yang telah dianjurkan oleh Allah swt. terdapat dalam Al-Qur'an surat Al-Nisa (3) : 29

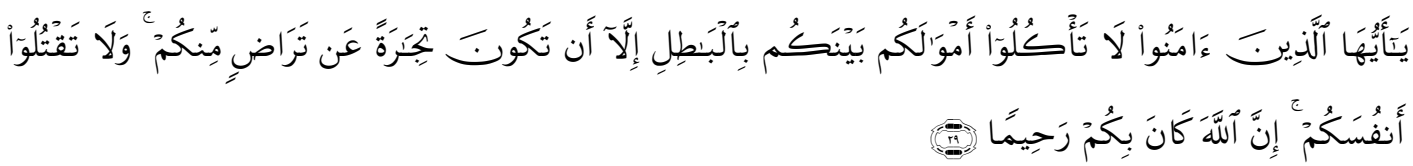

29. Hai orang-orang yang beriman, janganlah kamu saling memakan harta sesamamu dengan jalan yang batil, kecuali dengan jalan perniagaan yang Berlaku dengan suka sama-suka di antara kamu. dan janganlah kamu membunuh dirimu[287]; Sesungguhnya Allah adalah Maha Penyayang kepadamu.

[287] Larangan membunuh diri sendiri mencakup juga larangan membunuh orang lain, sebab membunuh orang lain berarti membunuh diri sendiri, karena umat merupakan suatu kesatuan.

${ }^{45}$ Nurul Ichsan Hasan, Perbankan Syariah Sebuah Pengantar (Jakarta: GP Press Group, 2014), hlm. 193.

${ }^{46}$ Hendi Suhendi, Fiqh Muamalah (Jakarta: Rajawali Pers, 2011), hlm. 46. 
Dari ayat tersebut dapat dimengerti bahwa konsep ridha yang dimaksud Allah ialah ketika segala sesuatu yang dikerjakan dan dapat dijalankan sesuai dengan perintah dan ketentuan Allah, maka pada saat itulah timbul keridhaan Allah swt. Sehingga dalam penyelesaian sengketa dianjurkan untuk dapat menjunjung adanya kerelaan dari para pihak. Sebagaimana konsep akad yang telah di jelaskan di atas, maka dalam praktiknya bahwa mediasi di BPSK Kota Mataram telah melakukan hal yang sama dengan konsep tersebut. Salah satu contoh dalam kasus No. 13/BPSK/III/2017 antara Bapak Suhardi (konsumen) dengan PT. Amanah Finance (pelaku usaha). Jadi, dalam kasus ini konsumen menginginkan adanya pemberian BPKB kendaraaan bermotor mengingat ia telah melunasi seluruh angsuran. Dengan kerelaan dan kesepakatan para pihak maka BPKB akhirnya diserahkan kepada konsumen. Sehingga dalam contoh kasus ini terlihat bahwa tanpa adanya kerelaan dan kesepakatan para pihak maka akan sulit nantinya menemukan titik temu.

Konsep ridha dalam mediasi, telah diterapkan pula oleh Rasulullah dalam Perjanjian Hudaibiyah. Dimana Rasulullah dalam Perjanjian Hudaibiyah telah menunjukkan sikap tidak memihak dan netral dalam memosisikan kaum muslimin dan kafir Quraisy terutama dalam proses negosiasi, selain itu terdapat pula unsure member dan unsure menerima dari kedua belah pihak, sehingga tidak ada yang merasa dirugikan satu sama lain. Pada dasarnya sulh memberikan kesempatan kepada para pihak untuk berdamai, menghentikan perselisihan dan mengukuhkan hubungan silaturahmi. Pemerintah Mesir telah menggunakan sulh sebagai jalan alternatif penyelesaian sengketa muamalah dan keluarga. Undang-undang Acara Mesir No. 13 Tahun 1968 mengharuskan adanya majelis sulh guna mengendalikan perdamaian di antara para pihak yang bersengketa. Berdasarkan Undang-undang Acara Mesir, majelis sulh dapat digunakan di pengadilan maupun di luar pengadilan. Masyarakat lebih banyak menggunakan sulh sebagai cara penyelesaian sengketa, ketimbang melalui proses hukum di pengadilan.

Islam sebagai bagian dari wadah perdamaian diharapkan dapat membawa perubahan-perubahan yang menjadikan seluruh umat di dunia merasa tenteram. Untuk dapat menyelesaikan dan menemukan jalan keluar atas konflik yang terjadi, maka Islam memiliki cara tersendiri yang dapat ditempuh oleh seluruh umat manusia dalam mencari solusi terhadap penyelesaian konflik. Salah satunya ialah (sulh) perdamaian merupakan suatu jenis akad (perjanjian) untuk mengakhiri perlawanan (perselisihan) antara dua orang yang berlawanan. Sebelum para pihak melakukan perdamaian maka terlebih dahulu mengetahui rukun-rukun perdamaian, sebagaimana di rumuskan oleh jumhur ulama, yaitu ${ }^{47}$ "1. Adanya kedua belah pihak yang melakukan sulh; 2. Adanya lafal ijab dan kabul; 3. Adanya kasus yang dipersengketakan; dan 4. Adanya bentuk perdamaian yang disepakati oleh kedua belah pihak". Apabila rukun-rukun tersebut terpenuhi maka perjanjian perdamaian di antara para pihak yang bersengketa telah berlangsung. Dengan sendirinya dari perjanjina 
perdamaian tersebut lahirlah suatu ikatan hukum, yang masing-masing pihak berkewajiban untuk memenuhi atau menunaikan pasal-pasal dalam perjanjian perdamaian. Akan tetapi apabila nantinya salah satu pihak tidak menunaikannya, maka dapat dituntut agar perjanjian itu dilaksanakan. Hal tersebut didukung oleh pendapat Abdurrahman al-Jaziry yang mengungkapkan apabila qabul berbeda dengan ijab, maka perdamaian dinyatakan tidak sah. ${ }^{48}$

Dalam melakukan perjanjian perdamaian, hukum Islam mengatur syarat sah atas suatu perjanjian perdamaian diklasifikasikan sebagai berikut: ${ }^{49}$

Menyangkut subjek (pihak-pihak yang mengadakan perjanjian perdamaian). Tentang subjek orang yang melakukan perdamaian haruslah orang yang cakap bertindak menurut hukum. Adapun orang yang cakap bertindak menurut hukum adalah orang yang telah dewasa menurut hukum. Orang yang melakukan perjanjian perdamaian, selain cakap bertindak menurut hukum, juga harus orang yang mempunyai kekuasaan atau mempunyai wewenang untuk melepaskan haknya atas hal-hal yang dimaksudkan dalam perdamaian tersebut.

Menyangkut objek perdamaian. Tentang objek perdamaian haruslah memenuhi ketentuan sebagai berikut: a) Berbentuk harta (dapat berupa benda berwujud seperti tanah dan dapat juga berupa benda tidak berwujud, seperti hak milik intelektual) yang dapat dinilai atau dihargai, dapat diserahterimakan, dan bermanfaat), b) Dapat diketahui secara jelas sehingga tidak melahirkan kesamaran dan ketidakjelasan, yang pada akhirnya dapat pula melahirkan pertikaian yang baru terhadap objek yang sama (sedangkan perdamaian memutus pertikaian untuk selama-lamanya).

Persoalan yang boleh didamaikan. Tidaklah segala sesuatu persoalan dapat didamaikan (diadakan perjanjian perdamaian). Adapun persoalan atau pertikaian yang boleh atau dapat didamaikan hanyalah sebatas menyangkut hal-hal berikut: a) Pertikaian itu berbentuk harta yang dapat dinilai, b) Pertikaian itu menyangkut hak manusia yang boleh diganti.

Oleh karena itu peneliti dapat menarik kesimpulan dari praktik mediasi antara konsumen dan pelaku usaha dalam pembiayaan mobil di BPSK Kota Mataram dalam konsep hukum Islam terdapat beberapa konsep yang sejalan dengan konsep Islam, yaitu adanya kerelaan antara kedua belah pihak, majelis dalam memutus perkara harus didasarkan atas prinsip musyawarah mufakat antar para pihak dan menjunjung tinggi keadilan dalam memberikan putusan perdamaian antar para pihak. Serta tetap tunduk pada rukun, syarat dan prinsip dalam perdamaian. Namun, BPSK Kota Mataram menggunakan istilah dan aturan-aturan yang sesuai dengan hukum acaranya.

\footnotetext{
${ }^{48}$ Syahrizal Abbas, hlm. 209.

${ }^{49}$ Suhrawardi K. Lubis., Farid Wadji, Hukum Ekonomi Islam (Jakarta: Sinar Grafika, 2012), hlm. 193.
} 


\section{Kesimpulan}

Dari hasil penelitian dan pembahasan di atas maka dapat ditarik kesimpulan sebagai berikut: Pertama, Mediasi antara konsumen dan pelaku usaha yang dilakukan BPSK Kota Mataram dalam penyelesaian sengketa pembiayaan mobil berjalan efektif. Namun, terdapat beberapa aspek yang harus lebih diperhatikan oleh BPSK Kota Mataram. Secara umum terdapat 12 tahapan dalam proses mediasi. Namun, pada dasarnya terdapat 3 tahapan khusus, yaitu: Tahap Permohonan, Tahap Persidangan, dan Tahap Putusan.

Kedua, penyebab timbulnya sengketa konsumen dalam kasus pembiayaan mobil yang ditangani di BPSK Kota Mataram sebagian besar karena adanya wanprestasi dan perbuatan melawan hukum. Dalam pelaksanaannya, terlepas apakah kesalahan atau kelalaian ada pada pelaku usaha maupun konsumen, pelaku usaha tetap bertanggung jawab dalam memberikan ganti rugi terhadap konsumen sesuai dengan kerugian yang sebenarnya. Sebaliknya konsumen juga tetap berusaha dalam pemenuhan prestasinya (janjinya).

Ketiga, mediasi dalam konsep hukum Islam secara umum tidak menentukan adanya tahapan-tahapan khusus, namun harus memperhatikan rukun, syarat serta prinsip, yaitu: keadilan, kesamaan, universal dan martabat manusia, penguatan sosial dengan berbuat baik, empati dan menaruh perhatian terhadap orang lain. Dimana ketentuan ini telah di tetapkan berdasarkan Al-Qur'an. Sehingga terdapat beberapa konsep dan aturan yang sejalan dengan praktik mediasi yang dijalankan di BPSK Kota Mataram yaitu adanya musyawarah dan kekeluargaan. Akan tetapi, secara teknis mediasi dalam penyelesaian sengketa konsumen di BPSK Kota Mataram tetap mengacu pada hukum acara tersendiri mengingat segala bentuk proses ataupun tata cara penyelesaian sengketa konsumen di BPSK tunduk pada aturan hukum positif.

\section{DAFTAR PUSTAKA}

Abbas, Syahrizal. Mediasi dalam Hukum Syariah Hukum Adat dan Hukum Nasional. Jakarta: Kencana, 2011.

Amriani, Nurnaningsih. Mediasi Alternatif Penyelesaian Sengketa Perdata di Pengadilan. Jakarta: Rajawali Pers, 2012

Asikin, Zainal dan Amirudin . Pengantar Metode Penelitian Hukum. Jakarta: Rajawali Pers, Cet. 9, 2016.

Hasan, Nurul Ichsan. Perbankan Syariah Sebuah Pengantar. Jakarta: GP Press Group, 2014.

Hutagalung, Sophar Maru. Praktik Peradilan Perdata dan Alternatif Penyelesaian Sengketa. Jakarta: Sinar Grafika, 2012. 
Irawan, Candra. Aspek Hukum dan Mekanisme Penyelesaian Sengketa di Luar Pengadilan (Alternative Dispute Resolution). Bandung: Mandar Maju, 2010.

Kementerian Agama RI. Al-Qur'an dan Terjemahnya. Bandung: Fokusmedia, 2010.

Lubis, Rukiyah dan Intan Nur Rahmawati. Win-Win Solution Sengketa Konsumen. Yogyakarta: Medpress Digital. Cet. 1. 2014.

Meliala, Djaja S. Perkembangan Hukum Perdata Tentang Benda dan Hukum Perikatan. Bandung: CV. Nuansa Aulia, 2007.

Nahrowi, "Permasalahan Hukum Pembiayaan Leasing di Indonesia", Jurnal Cita Hukum UIN Syarif Hidayatullah. No. 1. Vol. 1. Juni 2013.

Prasetyawati, Endang. "Konsep Hukum Pembiayaan Konsumen Di Masa Yang Akan Datang", Yustisia Vol.2 No.2 Mei - Agustus 2013.

Sihombing, Jonker. Peran dan Aspek Hukum dalam Pembangunan Ekonomi. Bandung: P.T. Alumni, 2010.

Silalahi, Ulber. Metode Penelitian Sosial. Bandung: PT Refika Aditama, 2010.

Suhendi, Hendi. Fiqh Muamalah. Jakarta: Rajawali Pers, 2011.

Sunaryo, Hukum Lembaga Pembiayaan. Jakarta: Sinar Grafika, 2014.

Tampi, Mariske Myeke dan Mia Hadiati. "Efektivitas Mediasi Dalam Penyelesaian Sengketa Konsumen Oleh Badan Penyelesaian Sengketa Konsumen (BPSK) Di D.K.I Jakarta". Jurnal Hukum Prioris. Vol. 6. No. 1. Tahun 2017.

Usman, Rachmadi. Mediasi di Pengadilan dalam Teori dan Praktik. Jakarta: Sinar Grafika, 2012.

Wadji, Farid dan Suhrawardi K. Lubis. Hukum Ekonomi Islam. Jakarta: Sinar Grafika, 2012. Zuriah, Nurul. Metodologi Penelitian Sosial dan Pendidikan Teori-Aplikasi. Jakarta: PT. Bumi Aksara, 2006.

Undang-Undang Nomor 8 Tahun 1999 tentang Perlindungan Konsumen.

Undang-Undang Nomor 42 Tahun 1999 tentang Jaminan Fidusia.

Kitab Undang-Undang Hukum Perdata (KUHPerdata).

Kepmenperindang 350/MPP/Kep/12/2001 tentang Kewenangan Badan Penyelesaian Sengketa Konsumen.

Peraturan Menteri Keuangan No. 130/PMK.010/2012 tentang Pendaftaran Jaminan Fidusia bagi Perusahaan Pembiayaan yang Melakukan Pembiayaan Konsumen untuk Kendaraan Bermotor dengan Pembebanan Jaminan Fidusia.

Wawancara dengan Yudi selaku pelaku usaha dari perusahaan pembiayaan Otto Finance, pada tanggal 6 Desember 2018, pukul 15.30 WITA

Wawancara dengan Suhardi, konsumen PT. Amanah Finance, pada tanggal 13 Januari 2018, pukul 14.00 WITA. 
Wawancara dengan Yuni Maryuzim, konsumen PT. Mandiri Tunas Finance, pada tanggal 12 November 2017, pukul 14.20 WITA

Wawancara dengan Ahmad bin Talibok, pelaku usaha di PT. Astra Credit Companies (ACC), pada tanggal 23 Januari 2018, pukul 11.40 WITA

Wawancara dengan Haerani, Ketua Badan Penyelesaian Sengketa Konsumen (BPSK) Kota Mataram, pada tanggal 8 Februari 2018, pukul 17.00 WITA.

Observasi di kantor Badan Penyelesaian Sengketa Konsumen (BPSK) Kota Mataram, Mataram, 13 November 2017. 
280 | Asy-Syari'ah Vol. 21 No. 2, Desember 2019 


\begin{abstract}
Asy-Syari'ah (P-ISSN : 2086-9029 E-ISSN: 2654-5675) is a periodical scientific journal that publishes various results of studies and research, literature review, and other scientific works whose scope covers the field of Islamic law/sharia, law and society in monodisciplinary, interdisciplinary, and multidisciplinary manners. The journal aims to expand and create innovative concepts, theories, paradigms, perspectives and methodologies in the above said scope. The Journal is published twice a year (june and december) by Faculty of Shariah and Law, Sunan Gunung Djati State Islamic University Bandung in collaboration with Asosiasi Sarjana Syariah Indonesia (ASSYI).
\end{abstract}

\title{
EDITORIAL OFFICE:
}

Fakultas Syariah dan Hukum UIN Sunan Gunung Djati Bandung Jl. Raya A.H. Nasution No. 105 Cibiru Kota Bandung, 40614

Tlp/Fax: +022-7802278 Faks. 022-7802278

Website http://journal.uinsgd.ac.id/index.php/asy-syariah/index

E-mail: Jurnalasy-syariah@uinsgd.ac.id 